IJIET, e-ISSN 2548-8430, p-ISSN 2548-8422, Vol. 2, No. 1, January 2018

International Journal of Indonesian Education and Teaching http://e-journal.usd.ac.id/index.php/IJIET

Sanata Dharma University, Yogyakarta, Indonesia

\title{
UTILIZING AUTHENTIC VIDEOS: AN ACTION RESEARCH TO ENHANCE STUDENTS' ABILITY IN DEVELOPING THEIR SPEAKING CONTENT
}

\author{
Yeskha Martika Megariani \\ Sanata Dharma University \\ yeskha.mm@gmail.com \\ https://doi.org/10.24071/ijiet.v2i1.959
}

received 1 October 2017; revised 2 November 2017; accepted 19 December 2017

\begin{abstract}
Conducting a classroom action research, this study explores how the utilization of authentic videos can enhance students' ability in developing the content of their speaking. A preliminary study which is done by the researcher shows that a group of $10^{\text {th }}$ grade students had a problem in developing their speaking content in English class. Therefore, the researcher determined to use authentic videos inorder to solve this problem and improve students' ability in developing speaking content. These authentic videos are expected to attract students' attention as well as give good and authentic models about delivering the message, speaking organization, idea development, and transitions. The findings, from students' score, interview, and observation, and its analysis indicate that the use of authentic videos were effective enough in enhancing students' speaking content development. Besides, students also learned how to pronounce certain expressions, use good intonation in telling something, manage their facial expression and body language when they speak with others, and so on.
\end{abstract}

Keywords: classroom action research, authentic videos, speaking content development

\section{Introduction}

Mastering certain language means we have to deal with at least four basic skills, such as listening skill, speaking skill, reading skill, and writing skill (Jacobs, 2013). We cannot choose to learn or teach reading and writing skills while omitting the other two skills because these four skills are connected one to another. In this case, teachers and schools should provide right portion in teachingthese four skills with the appropriate teaching approach and method (Celce- Murcia, 1991). On the other words, it must be fitted with students' needs and the topic of discussion.

This expectation is not in line with the reality. The assessment on English comprehension in Indonesian national examination that focuses on students' ability and understanding in listening, reading, and writing skills (Badan Standar Nasional Pendidikan, 2016) makes many teachers tend to avoid teaching speaking 
skill and concentrate on teaching other skills. Moreover, Hughes \& Reed (2017) argue that teaching speaking is difficult since there are many aspects to be considered in speaking, like arranging our sentences (structure), pronouncingsome words and managing our intonation (sound), and interacting with others or audiences and maintain our body language and eyes contact (organization and behavior). If there is no follow-up to this situation, students will find difficulties when they have to speak using English. This situation was found by the researcher when she conducted a teaching practice in one of private schools in Yogyakarta, Indonesia.

The researcher found that the students were not able to develop their speaking content. When they were asked to speak in front the class, they just mentioned the main idea related with the topic discussed without giving any supporting ideas. If it was done in pairs, their statements sometimes did not show that they were responding to their interlocutor. It is not in accordance with the basic rule of having a conversation (Febriyanti, 2013). In order to validate the datafrom this observation, the researcher asked the English teacher's opinion or perception about students' ability in developing their speaking content. He said that most of students did not want and/or able to develop their speaking content.

In order to overcome that problem, the researcher decided to use authentic videos because authentic videos can provide interesting teaching and learning activities as well as help students in giving good models of speaking content development (Heinich, Molenda \& Russell, 1982). This idea was supported by the school; they provided a viewer and a speaker in each class. Therefore, this study examines how the use of authentic videos can enhance students' ability in developing speaking content.

\section{Speaking content development}

Speaking is a kind of interaction between two or more people to deliver certain messages orally, ask something, or even command someone to do something (Luoma, 2005; Bygate, 2010). If someone starts talking, there must be something he/she wants to say. As what has been mentioned before, there are many aspects that should be considered in speaking, such as pronunciation, intonation, fluency, grammar, body language, and the most important aspect is the content of their speech (Hughes \& Reed, 2017; Nunan, 2001).

Speaking content is really important because it represents the goal(s) of our speaking and there is a message that will be conveyed in one's speaking content (Grice \& Skinner, 1995). This is in line with the purpose of having an interaction through speaking as delivered by Luoma and Bygate. Koch (1995) explains three main steps in developing our speaking content. The first step is determining our purpose or the message we want to convey. By knowing the purpose or message of our speaking, we will be able to make a note on the main points then elaborate it by using some supporting ideas that can be stated in the form of giving definition, example, statistic, argument, and so on (Koch, 1995).

In addition to elaborating supporting ideas based on the main message, we should pay attention on the 'movement' of these ideas. Koch (1995) and Zarefsky (1996) state that we can use appropriate transitions in the idea development or elaboration in order to make the audiences or the interlocutors understand every 
single idea we want to convey. These aspects, like delivering the message, speaking organization, idea development, transitions, and the speaking mechanism(fluency, intonation, and pronunciation) are used as the guideline to assess students' speaking performance in this study, especially in the speaking content development (Blaz, 2001; Brown, 2004; Grice \& Skinner, 1995; Koch, 1995;

Luoma, 2005).

Teachers will encounter many challenges in teaching speaking content development. One of these challenge is students prefer to do the same thing as what is presented in the handbook (Nunan, 2003). In this case, most students tend to change some parts in a handbook into their current situations, and they do not try to develop the speaking content by themselves. Therefore, the topic or material which is provided by teachers should fit with students' needs (Nation \& Newton, 2009). For example, in discussing descriptive text, it will be better if teacher give text about markets or demand and supply rather than about life cycle of butterfly. When teachers are able to choose topics that suit to students' needs, students will be able to develop ideas easily and independently when we ask them to speak (Brown, 2004).

\section{Utilizing authentic videos in English class}

Media selection that will be used in classroom activities cannot be done indiscriminately because the main purpose of media usage is to bring development on the teaching and learning activities (Eggen \& Kauchak, 2010). Therefore, media selection should be based on many aspects, like the learning goals or objectives (Kemp \& Smellie, 1989). Certain media are not always suitable to teach a material or topic, so teachers should analyze whether media X can be usedto teach topic A. Besides, media selection should also consider students' needs (Ampa, et. al., 2013) and students' learning characteristic (Woolfolk, 2009). If students are audio learners, teachers can use song or one's speech when they are teaching. On the other hand, teachers can use pictures or flash cards if their students are visual learners.

Based on the observation and interview which was done in the preliminary study, the participants of this study are audio and visual learners so the researcher decided to use authentic videos. The use of teaching media that suits with students' learning characteristic can attract students' attention because they like it (Woolfolk, 2009). Another reason why we can get students' attention by using authentic videos is the aspects or occurrences featured in a video are almost the same as what happens in the real life (Heinich, Molenda \& Russell, 1982). When students can enjoy the activities in the classroom, it will automatically increase students' motivation to learn and take a part in the teaching and learning activities (Sherman, 2003; ThiTuyetAnh, 2015).

In addition to facilitating students with the media which is in accordance with students' learning characteristic, authentic videos is expected to provide or show good language models for students, such as how to pronounce some wordsor how to develop a main idea (Sherman, 2003). The existence of good language models by using videos is really important since English is not students' native language and they cannot learn it from their environment (Nunan, 2003). Therefore, teachers should provide good language models for their students, either 
by always using English in the classroom or by showing videos. Basically, adolescents often try to do the same things like the role models (Santrock, 2007), hence the participants as adolescents are expected to be able to imitate what they see and hear in the videos, especially in the development of speaking content.

\section{Method}

The participants of this study were 17 students (10 male and 7 female) from language class. Since these students took language program as the discipline of their study, they were assumed and expected to have good language skills, as well as in English skills, when we compared to those from other disciplines of their study. It was because the selection of students' discipline of study was based on their choice, their grades in junior high school level, and the national examination score. However, the result of preliminary study indicated that the participants got hassle in arranging and developing the content of their speech in English class. They only mentioned the main point of the topic discussed without giving any elaboration.

In this study, the researcher also invited the English teacher of the students in language class to contribute as the informant about the difficulties experienced by the students, especially in speaking activities. Here, the English teacher as the one who had better understanding on students' strengths and weaknesses also gave information about students' characteristic and interest. This information was really helpful for the researcher in determining the method or media that would beused to solve the problem faced by the students in English class (Suryabrata, 2006). On the other hand, the English teacher was invited to be the observer who gave comment and/or feedback on the researcher and students performance during the implementation of this action research.

This study was done by conducting a classroom action research (CAR) that focused on the common issues or the existence problems in the classroom (Ary, et. al., 2010; Fraenkel \& Wallen, 2009). In this study, the researcher would try to find the solution of the problems that appeared in the preliminary study in order tomake an improvement on students' learning process or teachers' performance (Hendricks, 2009; McNiff \& Whitehead, 2011; Fraenkel \& Wallen, 2009). As what has been stated before, the result of preliminary study in this study indicated that the participants found difficulties in developing their speaking content. This data was acquired by observing the classroom activities and also interviewing the English teacher. Fraenkel \& Wallen (2009) and Mills (2011) stated that the problem solver should be implemented twice at the minimum. In this study, the first cycle is done to check authentic videos can enhance students' speaking content development and the second cycle is done to confirm or validate the data obtained in the first cycle.

The data from students' score was analyzed by using one of statistical techniques, $t$-test. Generally, $t$-test is a statistical technique that is used to test the hypothesis regarding the comparative of the mean scores of different groups or situations (Ary, et. al., 2010; Pallant, 2013). Here, students' scores as the raw data were inputted in SPSS program and the result of this program used to determine whether the use of authentic videos was effective enough to enhance students' 
ability in developing speaking content. In order to strengthen the data, the researcher also conducted a semi-structured interview in which the questions of the interview were pre-prepared (Burns, 2003; Mills, 2011). The researcher decided using triangulation design to provide the more valid and credible data since every data will complete one to another (Fraenkel \& Wallen, 2009).

\section{Findings and Discussion}

There are four essential elements that should be done in the main activities of classroom action research; these are plan, act, observe, and reflect (Fraenkel \& Wallen, 2009; Ary, et. al., 2010; Mills, 2011). Basically, the implementation of these four elements in cycle one and cycle two was almost the same. If there are some changes in cycle two, these are based on the observation and interview data in cycle one to improve the result of this study.

In the planning section, the researcher decided to use authentic videos for some considerations in order to solve the problem that appeared in preliminary study. The researcher also made lesson plan and prepared all teaching material, like handout, worksheet, videos, and so on. After that, the researcher taught the participants using authentic videos. The learning activities in cycle one and cycle two are various, such as comparing two videos, filling in the blanks while watching videos, taking notes on certain expressions on the videos, arranging jumbled sentences, and performing individually or in pairs. In this section, students' speaking performance were assessed by using scoring rubric. The researcher also interviewed four students about the use of authentic videos in the classroom activities. Here, two students from higher level scores and two students from lower level were chosen to ensure that authentic videos could really enhance students' speaking content development from all levels.

Together with the English teacher of this class, the researcher observed the teaching and learning activities, especially on the impact of utilizing authentic videos on students' ability in developing speaking content, and observed students' performance. The last section is reflecting. The reflection was based on the students' score as well as the data from observation and interview. In the first cycle, the researcher tried to find what aspects worked well or did not work well and needed improvement. This data was used as the guideline to make lesson planfor cycle two. On the other hand, the reflection in cycle two was done to make a conclusion of this study, whether authentic videos can enhance students' ability in developing speaking content or not.

\section{Students' improvement in developing speaking content}

The result of observation in cycle one and two indicated that there was an improvement on students' speaking skills, especially in developing speaking content. Students were able to elaborate the main ideas of their speaking. Instead of only mentioning the message of their speaking, students also tried to give explanation, evidence, example, or other additional information. It made the audiences could understand their speech. When it was done in pairs, students started responding their interlocutors so the conversation flew naturally.

“Today's teaching was very good. The students' participation in presenting dialogue and students' work in group were also great. They were quick to 
memorize their dialogue and good at developing their speaking content. The medium which was used by the researcher as the model for the students was precise. Here, the medium could make students able to imitate how to pronounce and how to use the expression of inviting." [English teacher]

The students' progress in developing speaking content was not only shown in the observation data, but students' scores in speaking performance also showed an improvement.

Table 1. Students' Scores in Preliminary Study, Cycle One, and Cycle Two

\begin{tabular}{clccc}
\hline No. & \multicolumn{1}{c}{ Name* } & Preliminary study & Cycle one & Cycle two \\
\hline 1. & Amaranth & 50,00 & 87,50 & 87,50 \\
2. & Begonia & 50,00 & 87,50 & $0,00 * *$ \\
3. & Bluebell & 79,17 & 83,33 & 91,67 \\
4. & Daisy & 66,67 & 83,33 & 95,83 \\
5. & Gladiolus & 62,50 & 70,83 & 83,33 \\
6. & Heather & 87,50 & 100,00 & 95,83 \\
7. & Hibiscus & 75,00 & 87,50 & 91,67 \\
8. & Iris & 79,17 & 79,17 & 87,50 \\
9. & Lilac & 87,50 & 91,67 & 100,00 \\
10. & Marjoram & 70,83 & 75,00 & 79,17 \\
11. & Mimosa & 79,17 & 95,83 & 95,83 \\
12. & Narcissus & 50,00 & 66,67 & 83,33 \\
13. & Orchid & 75,00 & 87,50 & 95,83 \\
14. & Peony & 79,17 & 83,33 & 87,50 \\
15. & Rosemary & 83,33 & 83,33 & 95,83 \\
16. & Sage & 54,17 & 79,17 & 83,33 \\
17. & Tansy & 75,00 & 91,67 & 95,83 \\
\hline
\end{tabular}

*) All names are pseudonyms.

**) This student did not come when the researcher assessed their performance in cycle two.

The researcher did not input the data above at once but the students' scores in preliminary study and in cycle one were inputted first and followed by the students' scores in preliminary study and in cycle two. Before doing these steps, the null hypothesis $\left(\mathrm{H}_{0}\right)$ and alternative hypothesis $\left(\mathrm{H}_{1}\right)$ were drawn. In order to find out which hypothesis is accepted, we need to take a look on the significant level $(\alpha)-$ the significant level in t-test analysis is 0.05 . Pallant (2013) explains that $\mathrm{H}_{0}$ is accepted if the actual significant two-tailed (sig.(-tailed)) is higher than the significant level, while $\mathrm{H}_{1}$ is accepted when the actual significant two-tailed is lower than the significant level.

In the first calculation using SPSS, the null hypothesis claimed that the scores in preliminary study $\left(\mu_{1}\right)$ are greater than or equal to the scores in cycle one $\left(\mu_{2.1}\right)$ $-\mathrm{H}_{0}: \mu_{1} \geq \mu_{2.1}$ - and the alternative hypothesis claimed that the scores in preliminary study $\left(\mu_{1}\right)$ are less than the scores in cycle one $\left(\mu_{2.1}\right)-\mathrm{H}_{1}: \mu_{1}<\mu_{2.1}$. The result of the data processing in cycle one showed that the $t$ value is -4.890 and the sig.(2-tailed) is 0.000 . Because the number of sig.(2-tailed) is lower than the 
IJIET Vol. 2, No. 1, January 2018

significant level, $\mathrm{H}_{0}$ is rejected and $\mathrm{H}_{1}$ is accepted. It means the scores in preliminary study are less than the scores in cycle one.

\section{$\Rightarrow$ T-Test}

[Dataset0]

\begin{tabular}{|c|c|c|c|c|c|}
\hline \multicolumn{6}{|c|}{ Paired Samples Statistics } \\
\hline & & Mean & $\mathrm{N}$ & Std. Deviation & $\begin{array}{c}\text { Std. Error } \\
\text { Mean }\end{array}$ \\
\hline \multirow[t]{2}{*}{ Pair 1 } & pre_study & 70.8341 & 17 & 13.01041 & 3.15549 \\
\hline & cycle1 & 84.3135 & 17 & 8.52997 & 2.06882 \\
\hline
\end{tabular}
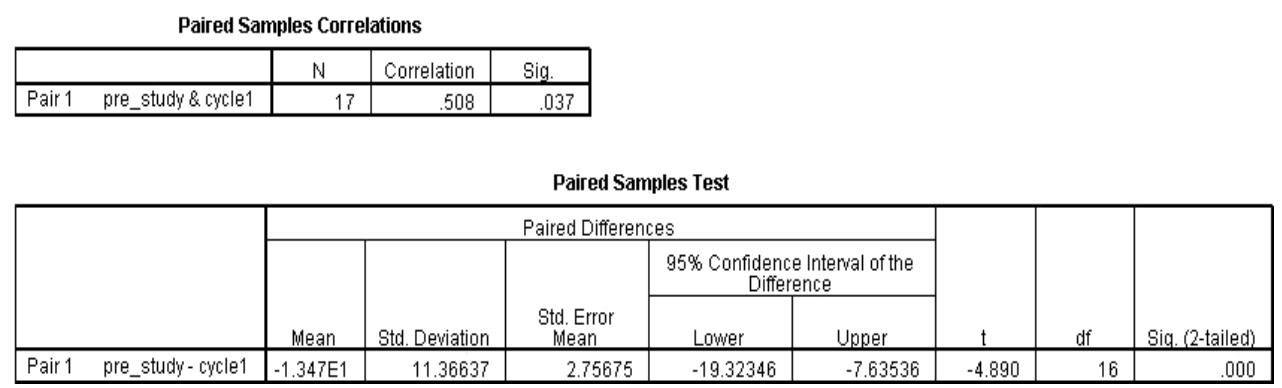

Figure 1. $t$-test result in cycle one

The process which was done in the second calculation using SPSS is the same. The researcher drew the null hypothesis and alternative hypothesis. The null hypothesis claimed that the scores in preliminary study $\left(\mu_{1}\right)$ are greater than or equal to the scores in cycle two $\left(\mu_{2.2}\right)-\mathrm{H}_{0}: \mu_{1} \geq \mu_{2.2}-$ and the alternative hypothesis claimed that the scores in preliminary study $\left(\mu_{1}\right)$ are less than the scores in cycle two $\left(\mu_{2.2}\right)-\mathrm{H}_{1}: \mu_{1}<\mu_{2.2}$. The result of the data processing in cycleone showed that the $t$ value is -8.116 and the sig.(2-tailed) is 0.000 . This result is the same as the calculation in cycle one; $\mathrm{H}_{0}$ is rejected and $\mathrm{H}_{1}$ is accepted. It means the scores in preliminary study are less than the scores in cycle two. 
IJIET Vol. 2, No. 1, January 2018

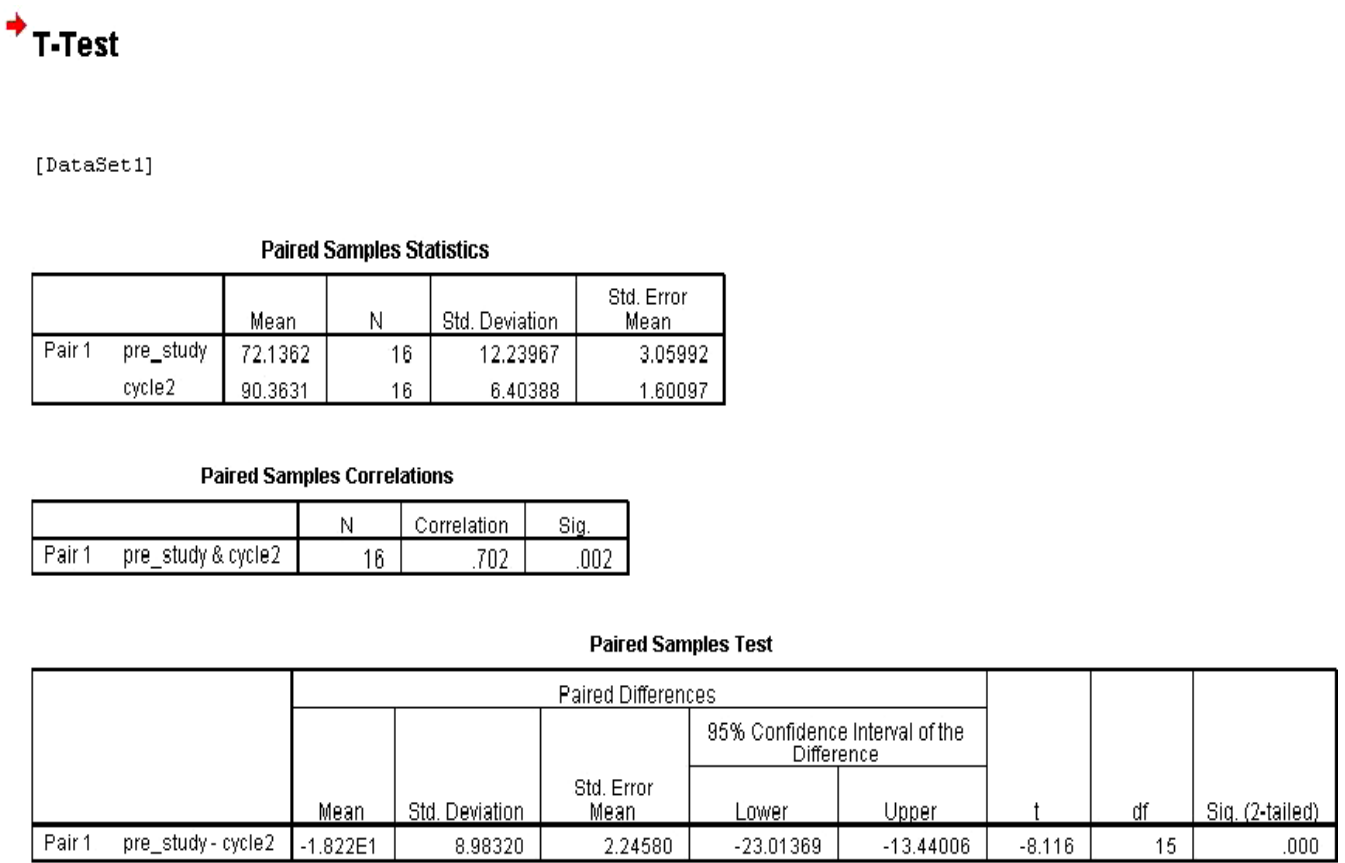

Figure 2. $t$-test result in cycle two

From both calculations above, the result showed that students' scores in preliminary study are less than students' scores in cycle one and cycle two. Therefore, the researcher concluded that the use of authentic videos was effective enough in enhancing students' speaking content development. In addition to increasing their speaking content development, it could also helped teacher to attract students' attention since they sometimes were busy doing other activities, like chatting, texting, or doing tasks from another subject, and helped teacher to deliver the lesson.

"They were happy and they were eager to do the assignment they got... Playing on video made the researcher's lesson much clearer. It created a big influence to the students. They did not only listen to the explanation but they also watched the process of something... Therefore, the use of a certain media for certain topics would make the students learned more effective." [English teacher]

\section{Students' notions on the use of authentic videos}

Generally, the participants agreed that authentic videos could help them in developing their speaking content. These students stated that they used to only mention the main idea of their speaking because they did not know what they should say. However, the use of authentic videos made them realized that speaking content development was really important. Besides, the activities before they should perform in front of the class guided them in elaborating their speaking content.

"At first, I did not know what to say. I was confuse and I wanted to end my dialogue or monologue as soon as possible... But the videos reminded me about the importance of developing my speaking. I also knew the important points in developing speaking content." [Amaranth] 
"When teacher asked me to speak using English, I only mentioned the essential ideas without giving explanation because my friend and I were unfamiliar with that and the teacher did not give enough example about it. It confused us. After I watched video, I know how a good dialog is delivered - the content, intonation, articulation, etc. It motivates me to do so." [Lilac]

In addition to giving knowledge about speaking content development and motivating the students to develop it, authentic videos could also give real models for students about a good speaking in terms of pronunciation, intonation, body language, fluency, and so on. One participant said that watching video enabled them to enrich their vocabularies.

"Overall, the learning activities, especially the videos, give me more knowledge about speaking. It also increases the number of vocabularies (in English) I have. It makes me feel more confidence when I must speak in front of my teacher and friends." [Heather]

A slightly different from other friends, Amaranth highlighted how videos really helped her in understanding the topic discussed since the videos made her want to join the lesson and pay attention on teacher's explanations.

"It is fun. It is different from the common one. I did not easily get bored anymore. The video makes me focus and pay attention on the lesson and it make me understand the lesson easier than when I only read the book or see the PowerPoint." [Amaranth]

\section{Conclusions}

In conclusion, this study attempts to enhance students' ability in developing speaking content by utilizing authentic videos. The result of t-test analysis presented the improvement on students' scores after the use of authentic videos in teaching and learning activities. Specifically, the students' scores in cycle one and cycle two are greater than the students' score in preliminary study. This result is strengthen by the English teacher's statement in the field notes when he observed the classroom activities and the students' opinion in the interviews. They agreed that the use of authentic video could provide good model for students in speaking content development, pronunciation, intonation, articulation, body language, fluency, and many more, so it motivated them to do the same thing (Santrock, 2007). It also enriched their vocabularies and it could help teachers in attracting students' attention and inviting them to contribute to the classroom activities.

There are some implications based on these findings. Even though thestudents have already got good model in speaking and got explanation about the topic through the use of authentic videos, teacher must guide the students and provide appropriate exercises in order to help students have better understanding on the topic discussed. Besides, the activity by using videos is listening and it tends to be more integrated with speaking activities; however, teachers can vary the activities by combining with writing, reading or vocabulary building activities. It is recommended for English teachers to utilize authentic videos as the learning media to improve students' speaking skills. Sherman (2003) states that teachers and students are able to get these kind of videos easily from many sources, such as television, film, internet, and many more. It means students can access it by 
themselves and use it to learn at home. It is also recommended for future researchers to further explore the advantages of authentic video in English class orexplore how to enhance students' speaking content development by using another method or media.

\section{References}

Ampa, A.T., Rasyid, M.A., Rahman, A., Haryanto D., \& Basri, M. (2013). The Students' Needs in Developing Learning Materials for Speaking Skills in Indonesia. Journal of Education and Practice, 4(17), 171-178.

Ary, D., Jacobs, L.C., \& Sorensen, C. (2010). Introduction to research in education ( ${ }^{\text {th }}$ ed.). Belmont: Wadsworth.

Badan Standar Nasional Pendidikan. (2016). Prosedur operasional standar penyelenggaraan ujian nasional tahun pelajaran 2016/2017. Jakarta Selatan. Retrieved October 6, 2017, from http://bsnp-indonesia.org/wpcontent/uploads/2017/01/0043-POS-UN-Tahun-2017-FINAL.pdf.

Bates, S. (2012, October 2). Invitation to a party - l3 - lesson 04 - English in Vancouver. Retrieved April 24, 2014, from http://www.youtube.com/watch?v=FBihpfTbSfE.

Blaz, D. (2001). A collection of performance tasks and rubrics: Foreign languages. New York: Eye on Education.

Brown, H.D. (2004). Language assessment: Principles and classroom practices. New York: Pearson Education, Inc.

Burns, A. (2003). Collaborative action research for English language teachers. New York: Cambridge University Press.

Bygate, M. (2010). Speaking. (C.N. Candlin \& H.G. Widdowson, Eds.). New York: Oxford University Press.

Celce-Murcia, M. (Ed.). (1991). Teaching English as a second or foreign language ( $2^{\text {nd }}$ ed.). Boston, Massachusetts: Heinle \& Heinle Publishers.

Crawford, M. (2011, November 9). Grade 6-lesson 14: Would you like to come to my house? Retrieved April 14, 2014, from http://www.youtube.com/watch?v=BEXVF1Ap0DM.

Drollinger, M. (2013, March 5). Metamorphosis. Retrieved May 10, 2014, from http://www.youtube.com/watch?v=Ka3q7bj45x0.

Eggen, P. \& Kauchak, D. (2010). Educational psychology: Windows on classrooms $\left(8^{\text {th }}\right.$ ed.). New York: Pearson Education, Inc.

Febriyanti, E.R. (2013). Teaching speaking of English as a foreign language: Problems and solutions. Jurnal Bahasa dan Sastra, 1(2), 1-16.

Fraenkel, J.R. \& Wallen, N.E. (2009). How to design and evaluate research in education ( $7^{\text {th }}$ ed.). New York: McGraw-Hill.

Grice, G.L. \& Skinner, J.F. (1995). Mastering public speaking ( $2^{\text {nd }}$ ed.). Boston: Allyn and Bacon.

Heinich, R., Molenda, M., \& Russell, J.D. (1982). Instructional media and the new technologies of instruction. Hoboken: John Wiley \& Sons, Inc.

Hendricks, C. (2009). Improving schools through action research: A comprehensive guide for educators. Upper Saddle River: Pearson. 
Hughes, R. \& Reed, B.S. (2017). Teaching and researching speaking ( $3^{\text {rd }}$ ed.). New York: Routledge.

Jacobs, H.H. (2013). Active literacy across the curriculum: Strategies for reading, writing, speaking, and listening. New York: Routledge.

Kemp, J.E. \& Smellie, D.C. (1989). Planning, producing and using instructional media. New York: Harper and Row Publishers, Inc.

Koch, A. (1995). Speaking with a purpose. Boston: Allyn and Bacon.

Luoma, S. (2005). Assessing speaking. (J.C. Alderson \& L.F. Bachman, Eds.). New York: Cambridge University Press.

McNiff, J. \& Whitehead, J. (2011). Doing and writing action research. London: SAGE Publications Ltd.

Mills, G.E. (2011). Action research: A guide for the teacher research (4 ${ }^{\text {th }}$ ed.). New York: Pearson Education, Inc.

Nation, I.S.P. \& Newton, J. (2009). Teaching ESL/EFL listening and speaking. New York: Routledge.

Nunan, D. (2001). Designing task for the communicative classroom. Cambridge: Cambridge University Press.

Nunan, D. (Ed.). (2003). Practical English language teaching. New York: The McGraw-Hill Companies, Inc.

Pallant, J. (2013). SPSS survival manual ( $5^{\text {th }}$ ed.). New York: McGraw-Hill.

Santrock, J.W. (2007). Adolescence (11 ${ }^{\text {th }}$ ed.). (Benedictine Widyasinta, Trans.). Jakarta: PT Gelora Aksara Pratama. (Original work published 2007).

Sherman, J. (2003). Using authentic video in the language classroom. New York: Cambridge University Press.

Suryabrata, S. (2006). Psikologi pendidikan. Jakarta: PT Raja Grafindo Persada.

The Weather Channel. (2013, June 27). Flash flooding explained. Retrieved May 7, 2014, from http://www.youtube.com/watch?v=o3j02MXcRSs.

ThiTuyetAnh, N. (2015). The key principles for development of speaking. International Journal on Studies in English Language and Literature, 3(1), 49-53.

Woolfolk, A. (2009). Educational psychology: Active learning edition (10 ${ }^{\text {th }}$ ed.). (Helly Prajitno Soetjipto \& Sri Mulyantini Soetjipto, Trans.). Yogyakarta: Penerbit Pustaka Belajar. (Original work published in 2008).

Zarefsky, D. (1996). Public speaking: Strategies for success. Boston: Allyn and Bacon. 